\title{
Immunohistochemical Evidence of Pancreatic $\beta$-cell Regeneration in streptozotocin-induced type 2 Diabetic Rats treated with Gymnema sylvestre Extract
}

\author{
Hafizur RM ${ }^{1 *}$, Fatima $\mathbf{N}^{2}$ and Shaukat $\mathbf{S}^{2}$
}

${ }^{1}$ Dr. Panjwani Center for Molecular Medicine and Drug Research, International Center for Chemical and Biological Sciences, University of Karachi, Karachi-75270, Pakistan ${ }^{2}$ Pakistan Council of Scientific \& Industrial Research (PCSIR), Karachi-75280, Pakistan

\begin{abstract}
The effective dose Gymnema sylvestre (GS) leaves methanolic extract (400 mg/kg) was administered orally to neonatally streptozotocin-induced non-obese type 2 diabetic rats for 28 days and fasting glucose, serum insulin and $\beta$-cell function were measured after the treatment periods. Pancreatic $\beta$ - and $\alpha$-cells were identified by immunohistochemistry and $\beta$-cells number was evaluated by morphometric analysis. GS extract showed antidiabetic activity through improving serum insulin and $\beta$-cell function. The $\beta$-cells number was increased significantly in the GS-treated diabetic rats. The immunohistochemal data revealed presence of few newly formed insulin positive $\beta$-cells in the GS-treated diabetic islets. This is the direct immunohistochemal evidence of $\beta$-cells regeneration and/ or neoformation in pancreatic islets by GS extract. Cluster of $\beta$-cells without any $\alpha$-cells were appeared in GS-treated diabetic rats, not in STZ-induced diabetic control rats, suggesting $\beta$-cells regeneration in GS-treated pancreas rather than stem-cell induced growth.
\end{abstract}

Keywords: Gymnema sylvestre; $\beta$-cell function; $\beta$-cell regeneration; Immunohistochemistry

Abbreviations: GS: Gymnema Sylvestre; STZ: Streptozotocin; DAPI: 4,6-Diamidino-2-Phenylindole; Db: Diabetic; GB: Glibenclamide

\section{Introduction}

Gymnema sylvestre (GS) has been used for the treatment of diabetes in Indo-Pak region for centuries. GS extract has been reported to have anti-diabetic effects in different animal models of diabetes by increasing serum insulin levels and attenuating blood glucose responses during oral glucose tolerance tests [1-13]. The mechanism of anti-diabetic effect of GS extract has been explored in some extent and $\beta$-cells regeneration was postulated one of the possible mechanisms. However, these studies lack the direct evidence of pancreatic $\beta$-cells regeneration. The present study was designed to explore pancreatic $\beta$-cells regeneration by GS extract in streptozotocin-induced non obese type 2 diabetic rats by immunohistochemical method for triple staining of insulin, glucagon and nuclei along with morphometric analysis.

\section{Methods}

\section{Preparation of extract}

GS leaves $(2 \mathrm{~kg})$ were purchased from a LaluKhet market of Karachi, Pakistan. Leaves were authenticated by a taxonomist, University of Karachi and voucher specimen (No. 86478) was deposited in Karachi University Herbarium, Pakistan. The powder of the leaves was soaked into aqueous $80 \%$ methanol for $72 \mathrm{~h}$ at room temperature 2 times. Pooled extracts were filtered, combined and evaporated to dryness under vacuum by using a rotary evaporator. Finally, the crude extract was freeze dried to give the experimental extract (140.5 gm). The extract was dissolved in water to make suspension and given to experimental rats.

\section{HPLC analysis of GS extract}

Standardization of methanolic extract of GS was performed by RP-HPLC (Agilent ChemStation 261100, USA) system comprising of binary pump with degasser, auto sampler with column oven, and
DAD detector. Data acquisition and integration was controlled by ChemStation software. A Merck C-18 (Hiber $250 \times 4.6$ Purosphere STAR RP-18e $(5 \mu \mathrm{m})$ column was used. The mobile phase was composed of A (water: acetic acid, 98:2) and B (methanol) in the gradient mode so that the concentrations of mobile phase B became $0-100 \%$ in 15 minutes. Flow rate was $1.0 \mathrm{ml} / \mathrm{min}$ throughout the analysis. The samples and standard were injected through an auto sampler. The injection volumes of standard GA and methanolic extract of GS was $20 \mu \mathrm{l}$. Column oven temperature was maintained at $25^{\circ} \mathrm{C}$. The detection wavelength of UV was $257 \mathrm{~nm}$. A standard gymnemic acid (GA) solution was prepared by weighing $10 \mathrm{mg}$ of standard in $5 \mathrm{ml}$ of $50 \%(\mathrm{v} / \mathrm{v})$ aqueous methanol. The solution of methanolic extract of GS was prepared by dissolving $1 \mathrm{~g}$ in a $100 \mathrm{ml}$ volumetric flask and made up volume up to $100 \mathrm{ml}$ with mobile phase. All samples were filtered with $0.45 \mu \mathrm{m}$ Millex-HN syringe driven filter unit (Millpore, Bedford, USA) and preserved at $4^{\circ} \mathrm{C}$ prior to analysis.

\section{Development of non-obese type 2 diabetic rats}

A freshly prepared streptozotocin (STZ) solution of $90 \mathrm{mg} / \mathrm{kg}$ in citrate buffer ( $\mathrm{pH} 4.5$ ) was injected intraperitoneally to 2-day-old Wistar pups to obtain non-obese type 2 diabetic rats. After three months of STZ induction, an oral glucose tolerance test was performed with 3 $\mathrm{g} / \mathrm{kg}$ glucose. The rats having fasting blood glucose levels of 7.7-12.1 $\mathrm{mmol} / \mathrm{l}$ at $0 \mathrm{~min}$ and showed the maximum rise at $45 \mathrm{~min}(12.7-19.5$

*Corresponding author: Hafizur RM, Dr. Panjwani Center for Molecular Medicine and Drug Research, International Center for Chemical and Biological Sciences, University of Karachi, Karachi-75270, Pakistan, Tel: 922134824934; E-mail: hafizpcmd@yahoo.com

Received May 11, 2015; Accepted June 15, 2015; Published June 17, 2015.

Citation: Hafizur RM, Fatima N, Shaukat S (2015) Immunohistochemical Evidence of Pancreatic $\beta$-cell Regeneration in streptozotocin-induced type 2 Diabetic Rats treated with Gymnema sylvestre Extract. J Cytol Histol 6: 342. doi:10.4172/21577099.1000342

Copyright: (C) 2015 Hafizur RM, et al. This is an open-access article distributed under the terms of the Creative Commons Attribution License, which permits unrestricted use, distribution, and reproduction in any medium, provided the original author and source are credited. 
mmol/l) were included in this study. The use of experimental animals in this study was conducted under the guidance of the basic standards in the care and use of laboratory animals, which has been prepared and published by the National Institutes of Health. The study protocol has been approved by the Research Ethics committee at ICCBS, University of Karachi, Pakistan.

\section{Acute effect of GS on blood glucose}

An acute blood glucose lowering effects of GS extract was performed in type 2 diabetic rats to select the dosage for chronic study. Diabetic rats were fasted overnight and divided into 5 groups (7 rats/group). Gr 1 (Db), diabetic control rats received only water; Gr 2 (Db+GS-200), Gr 3 (Db+GS-400), and Gr 4 (Db+GS-600), diabetic rats received 200, 400 and $600 \mathrm{mg} / \mathrm{kg}$ GS extract, respectively. Gr $5(\mathrm{Db}+\mathrm{GB})$, diabetic rats received $5 \mathrm{mg} / \mathrm{kg}$ glibenclamide. The extract and glibenclamide were given by gavage needle to the diabetic rats. Control rats were given an equivalent volume of water. Blood glucose was measured at $0,1,2$ and $3 \mathrm{~h}$ after oral 29 administration of GS extract.

Chronic extract treatment, collection of blood samples and pancreas for biochemical and immunohistochemical analysis

The GS extract ( $400 \mathrm{mg} / \mathrm{kg} / \mathrm{day})$ and glibenclamide $(5 \mathrm{mg} / \mathrm{kg}$ ) were given orally once daily by gavage needle to the diabetic rats. After 28 days of treatment, rats were sacrificed after giving anesthesia (sodium thiopental, $60 \mathrm{mg} / \mathrm{kg}$ ) and their venous blood were collected. Blood samples were centrifuged and serum was separated within $30 \mathrm{~min}$, aliquoted and kept at $-80^{\circ} \mathrm{C}$ for biochemical assay. After collection of blood, pancreata were excised and tissue were fixed in buffered formalin, sectioned and processed for immunohistochemical analysis. Serum insulin was measured using rat ELISA kit (Crystal Chem Inc., IL, and USA). Pancreatic $\beta$-cell function (HOMA \%B) was calculated from fasting glucose and fasting insulin by HOMA-CIGMA software [14]. Insulin and glucagon immunostaining and morphometry were performed as described previously $[15,16]$.

\section{Statistical analysis}

Statistical analyses were performed by using the SPSS 12.0 statistical package for Windows (SPSS, Inc., Chicago, IL, USA). All values were expressed mean \pm S.E.M. To compare data between and within group unpaired and paired t-tests (2-tailed) were performed, respectively. Differences were considered significant at $\mathrm{p}<0.05$.

\section{Results and Discussion}

\section{Standardization of methanolic extract of GS}

GS was standardized with reverse phase liquid chromatography by using GA as a marker compound. Figure 1 shows chromatogram of GS extract. GS extract showed the presence of several peaks eluted at various retention times, 2.7, 3.3, and $4.6 \mathrm{~min}$. The peak of GA appeared as a major peak at retention time of $2.7 \mathrm{~min}$ in the GS chromatogram. It was found that the concentration of GA was $10 \%(w / w)$. In this way the consistency of GS extract could be done by adjusting the concentration of the marker compound. The concentration of GA found in our HPLC analysis also in line with studies of Pandey and Yadav [17].

\section{Acute effect of GS on the blood glucose level in experimental diabetic rats}

The effects of oral administration of three different doses of the GS extract on blood glucose levels of STZ-induced type 2 diabetic rats are presented in Figure 2. Very little change in blood glucose levels were observed in water treated diabetic rats. In sharp contrast, oral administration of GS extract lowered blood glucose in a dose- and timedependent manner. The blood glucose lowering effect of $200 \mathrm{mg} / \mathrm{kg}$ dose reached significance $(\mathrm{p}<0.01)$ at 3 -h of GS treatment $(18.9 \pm 3.3 \%$ reduction). Interestingly, both 400 and $600 \mathrm{mg} / \mathrm{kg}$ doses significantly decreased the blood glucose levels at $2 \mathrm{~h}$ and $3 \mathrm{~h}$. A maximum decrease of $31.5 \%(\mathrm{p}<0.01)$ was observed with $400 \mathrm{mg} / \mathrm{kg}$ of GS extract at $3 \mathrm{~h}$. Hence, the dosage was selected as $400 \mathrm{mg} / \mathrm{kg} /$ day for chronic study.

\section{Chronic effect of GS extract on blood glucose, serum insulin and $\beta$-cell function}

There was a little change in fasting blood glucose in case of untreated diabetic rats during the experimental periods (Table 1). The blood glucose of the GS-treated diabetic rats significantly decreased compared with untreated diabetic rats $(7.24 \pm 0.33$ vs. $11.06 \pm 1.22$ $\mathrm{mmol} / \mathrm{l}, \mathrm{p}<0.001)$. Standard drug glibenclamide also lowered the blood glucose level $(5.75 \pm 0.53 \mathrm{mmol} / \mathrm{l})$ significantly $(\mathrm{p}<0.001)$ compared with untreated diabetic rats. Very little alteration of serum insulin was observed in the untreated diabetic rats during the experimental periods

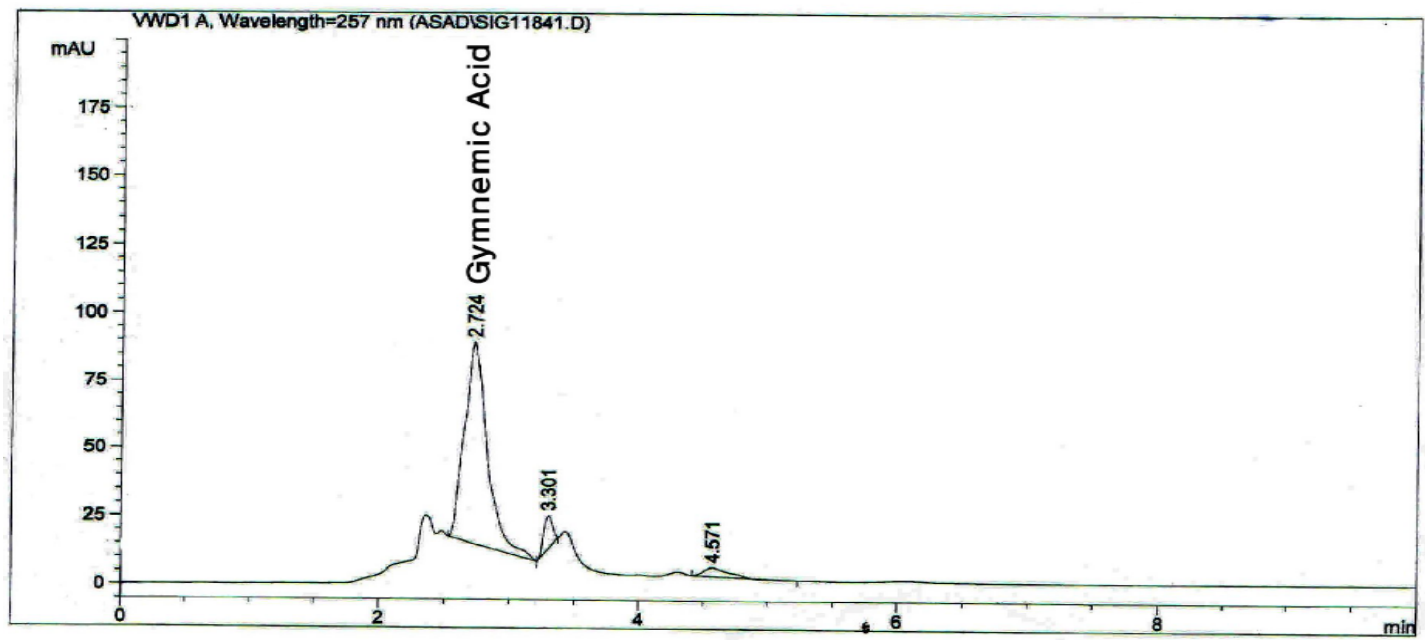

Table 1: Effect of GS extract on fasting blood glucose, fasting serum insulin and $\beta$-cell function in diabetic rats. 
Time (hour)

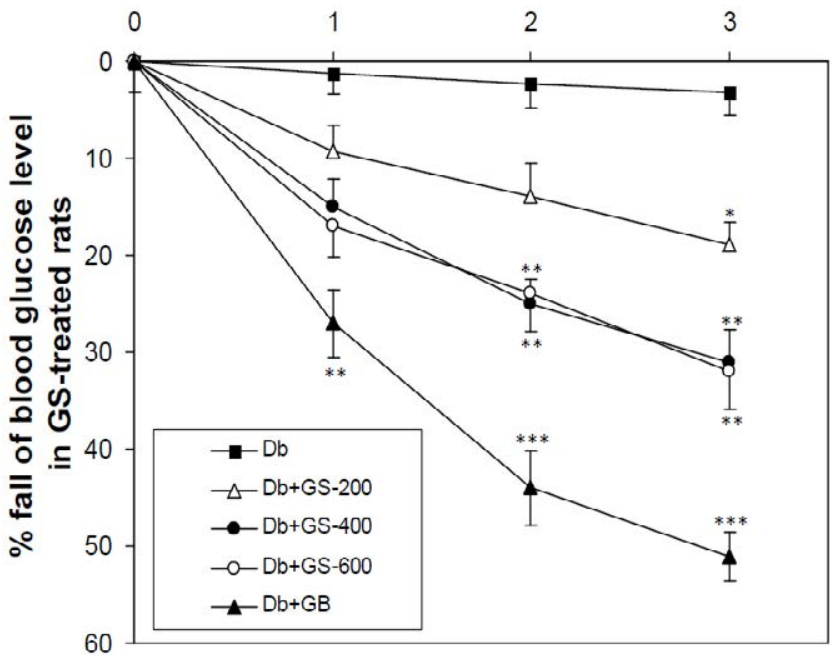

Table 1: Effect of GS extract on fasting blood glucose, fasting serum insulin and $\beta$-cell function in diabetic rats.

\begin{tabular}{|c|c|c|c|c|c|c|}
\hline \multirow{3}{*}{ Group } & \multirow{2}{*}{\multicolumn{2}{|c|}{$\begin{array}{l}\text { Fasting } \\
\text { glucose } \\
\text { (mmol/l) }\end{array}$}} & \multicolumn{2}{|c|}{ Fasting serum insulin } & \multicolumn{2}{|c|}{$\beta$-cell function } \\
\hline & & & (pmol/l) & & (\%) & \\
\hline & Day 1 & Day 29 & Day 1 & Day 29 & Day 1 & Day 29 \\
\hline $\begin{array}{l}\text { Diabetic } \\
(n=9)\end{array}$ & $9.65 \pm 1.04$ & $11.06 \pm 1.22$ & $39.05 \pm 2.25$ & $34.87 \pm 2.48$ & $24.8 \pm 2.7$ & $19.7 \pm 3.9$ \\
\hline $\begin{array}{l}\text { GS-treated } \\
(n=11)\end{array}$ & $10.13 \pm 1.02$ & $7.24 \pm 0.33^{\circ}$ & $37.64 \pm 2.35$ & $72.19 \pm 5.35^{*}$ & $21.5 \pm 3.6$ & $63.4 \pm 7.5^{*}$ \\
\hline $\begin{array}{l}\text { GB-treated } \\
(n=8)\end{array}$ & $9.02 \pm 0.53$ & $5.75 \pm 0.53^{\circ}$ & $41.17 \pm 3.58$ & $83.74 \pm 6.72^{*}$ & $28.6 \pm 2.7$ & $108.5 \pm 8.7^{t}$ \\
\hline
\end{tabular}

Table 1: Effect of GS extract on fasting blood glucose, fasting serum insulin and $\beta$-cell function in diabetic rats.

(Table 1). When the diabetic rats were treated with GS extract for 28 days, significant increase in serum insulin was observed compared to untreated diabetic rats $(72.19 \pm 5.35$ vs. $34.87 \pm 2.48 \mathrm{pmol} / \mathrm{l}, \mathrm{p}<0.001)$. Glibenclamide also increased the serum insulin level $(83.74 \pm 6.72$ $\mathrm{pmol} / \mathrm{l})$ significantly. Significant improvement of $\beta$-cell function was also observed in GS-treated diabetic rats $(63.4 \pm 7.5 \%$ vs. $19.7 \pm 3.9 \%$, $\mathrm{p}<0.001)$. The increase in serum insulin and $\beta$-cell function by GS might be due to the modulation and/or regeneration in the pancreatic $\beta$-cells.

\section{Immunohistochemical and morphometric studies on the} pancreas

In diabetic rats, pancreatic islets showed mild to moderate destruction of $\beta$-cells (Figure 3A), the characteristic features of nonobese type 2 diabetes. The $\alpha$-cells seemed to be exhausted 28with the compensatory work load to occupy the islet area and the intense staining could be seen 29 in $\alpha$-cells within diabetic islets. In contrast, when diabetic rats were treated with GS extract, islets showed bright and sparkling staining of insulin positive $\beta$-cells (Figure $3 \mathrm{~B}$ ). The $\alpha$-cells are reduced in ratio to $\beta$-cells in GS-treated group. The GS treatment showed few newly formed $\beta$-cells in the pancreas with no surrounding $\alpha$-cells (Figure $3 \mathrm{~B}$ ). This is the direct evidence of $\beta$-cell regeneration and/or neoformation by GS extract. The generation of $\beta$-cells by GS may be due to direct regeneration and/or neoformation or indirectly by stimulating the NGN 3.1, Mafa, PDX-1/4 or other proliferating factor, that stimulate

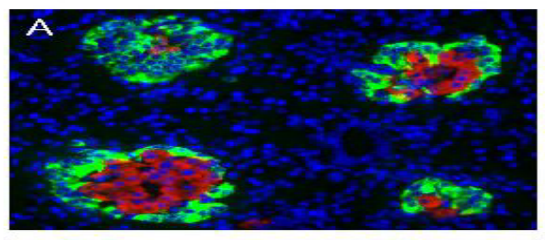

Figure 3
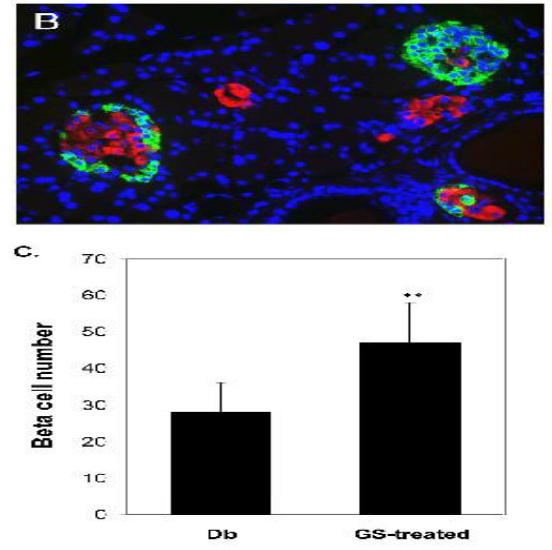

Figure 3: Immunohistochemical (A, B) and morphometric (C) analyses on the pancreas in different experimental groups. Sections in rat pancreas stained immunohistochemistry for insulin-positive $\beta$-cells (red), glucagon-positive $\alpha$-cells (green), and nuclei (blue) of pancreatic islets in (A) untreated diabetic (B) GS-treat diabetic rats. Magnification: 20X. Morphometric analysis of $\beta$-cell number $(C)$ in pancreatic islets of diabetic and GS-treated rats. All values are expressed as mean \pm SEM. Results represent the average from 6-8 rats with an average of $60-100$ fields per rat. ${ }^{*} \mathrm{P}<0.01$ versus diabetic group.

$\beta$-cell regeneration. The intense staining of nuclei reflecting nuclear activity of non-islet pancreas generate another hypothesis that newly formed $\beta$-cells mass without surrounding $\alpha$-cells is generated by nonislet cells of pancreas. The morphometric data showed that the $\beta$-cells number in the islets of the GS-treated rats was significantly higher than that of the untreated diabetic rats (Figure 3C). This further suggests that GS may have a role in the regeneration or revitalization of the $\beta$-cells or in the recovery of the partially damaged $\beta$-cells. Our data suggest that GS extract treatment produced regeneration in STZ-induced diabetic pancreas rather than embryonic like stem cell differentiation to $\beta$-cells. If the $\beta$-cells growth is due to very small embryonic like stem cells then it should appear in STZ-induced diabetic control rats as well. Cluster of only $\beta$-cells were appeared in GS-treated pancreas, not in STZ-induced diabetic control pancreas, suggesting that $\beta$-cells regeneration in GStreated pancreas and this regeneration is not due to stem-cell induced growth. Additionally, if the stem cell induced growth occurred in GStreated pancreas, then regeneration should result in both $\beta$-cells and $\alpha$-cells. However, in our study we found that cluster of $\beta$-cells without any $\alpha$-cells in GS-treated pancreas (Figure 3B). These findings further confirmed the regeneration of $\beta$-cells in GS-treated pancreas and exclude the possibility of very small embryonic like stem cells induced growth of $\beta$-cells.

\section{Acknowledgements}

This work was supported by a HEC grant (No. 20-1963/ $\mathrm{R} \& \mathrm{D} / 10 / 9164)$ to $M$. Hafizur Rahman from the Higher Education Commission, Pakistan. The authors declare that there is no conflict of interest that could be perceived as prejudicing the impartiality of the research reported. 
Citation: Hafizur RM, Fatima N, Shaukat S (2015) Immunohistochemical Evidence of Pancreatic $\beta$-cell Regeneration in streptozotocin-induced type 2 Diabetic Rats treated with Gymnema sylvestre Extract. J Cytol Histol 6: 342. doi:10.4172/2157-7099.1000342

\section{References}

1. Gupta SS (1961) Inhibitory effect of Gymnema sylvestre (Gurmar) on adrenaline-induced hyperglycemia in rats. Indian J Med Sci 15: 883-887.

2. Gupta SS (1963) Effect of Gymnema sylvestre and Pterocarpus marsupium on glucose tolerance in albino rats. Indian J Med Sci 17: 501-505.

3. Mhaskar KS, Caius JF (1930) A study of Indian medicinal plants. II. Gymnema sylvestre. Indian Med Res Memoirs 16: 1-35.

4. Okabayashi Y, Tani S, Fujisawa T, Koide M, Haseqawa H, et al. (1990) Effect of Gymnema sylvestre, R.Br. on glucose homeostasis in rats. Diab Res Clin Pract 9: 143-148.

5. Shanmugasundaram KR, Panneerselvam $C$, Samudram $P$, Shanmugasundaram ER (1983) Enzyme changes and glucose utilisation in diabetic rabbits: the effect of Gymnema sylvestre, R.Br. J Ethnopharmacol 7: 205-234.

6. Shanmugasundaram ER, Rajeswari G, Baskaran K, Rajesh Kumar BR, Radha SK, et al. (1990) Use of Gymnema sylvestre leaf extract in the control of blood glucose in insulin-dependent diabetes mellitus. J Ethnopharmacol 30: 281-294.

7. Srivastava Y, Nigam SK, Bhatt HV, Verma Y, Prem AS (1985) Hypoglycemic and life- prolonging properties of Gymnema sylvestre leaf extract in diabetic rats. Isr J Med Sci 21: 540-542.

8. Srivastava Y, Bhatt HV, Jhala Cl, Nigam SK, Kumar A, et al. (1986) Ora Gymnema sylvestre R.Br. leaf extracts inducing protracted longevity and hypoglycemia in alloxan diabetic rats: review and experimental study. Int $\mathrm{J}$ Crude Drug Res 24: 171-176.

9. Terasawa H, Miyoshi M, Imoto $\mathrm{T}$ (1996) Effect of long-term administration of Gymnema sylvestre watery-extract on variations of body weight, plasma glucose, serum triglyceride, total cholesterol and insulin in Wistar fatty rats. Yonago Acta Med 37: 117-128.
10. Baskaran K, Kizar AB, Radha SK, Shanmugasundaram ER (1990) Antidiabetic effect of a leaf extract from Gymnema sylvestre in non-insulin-dependent diabetes mellitus patients. J Ethnopharmacol 30: 295-300.

11. Khare AK, Tondon RN, Tewari JP (1983) Hypoglycaemic activity of an indigenous drug (Gymnema sylvestre, 'Gurmar') in normal and diabetic persons. Indian J Physiol Pharmacol 27: 257-258.

12. Shanmugasundaram KR, Panneerselvam $C$, Samudram $P$, Shanmugasundaram ERB (1981) The insulinotropic activity of Gymnema sylvestre, R. Br. an Indian medical herb used in controlling diabetes mellitus. Pharmacol Res Commun 13: $475-486$.

13. Al-Romaiyan A, Liu B, Asare-Anane H, Maity CR, Chatterjee SK, et al. (2010) A novel Gymnema sylvestre extract stimulates insulin secretion from human islets in vivo and in vitro. Phytother Res 24: 1370-1376.

14. Matthews DR, Hosker JP, Rudenski AS, Naylor BA, Treacher DF, et al. (1985) Homeostasis model assessment: insulin resistance and B-cell function from fasting plasma glucose and insulin concentrations in man. Diabetologia 28 : 412-419.

15. Hafizur RM, Kabir N, Chishti S (2011) Modulation of pancreatic $\beta$-cells in neonatally streptozotocin-induced type 2 diabetic rats by the ethanolic extract of Momordica charantia fruit pulp. Nat Prod Res 25: 353-367.

16. Hafizur RM, Kabir N, Chishti S (2012)Asparagus officinalis extract controls blood glucose by improving insulin secretion and $\beta$-cell function in streptozotocininduced type 2 diabetic rats. Br J Nutr 108: 1586-1595

17. Pandey AK, Yadav S (2010) Variation in gymnemic acid content and nondestructive harvesting of Gymnema sylvestre (Gudmar). Pharmacognosy Res 2: $309-312$. 